\title{
Ohranverkkolaikun (Pyrenophora teres) populaatioiden perinnöllinen muuntelu
}

\author{
Marjo Serenius ${ }^{1)}$, Marja Jalli2), Nina Mironenko ${ }^{3)}$ ja Outi Manninen ${ }^{1)}$ \\ ${ }^{1}$ MTT (Maa- ja elintarviketalouden tutkimuskeskus), Kasvintuotannon tutkimus, Myllytie 10, 31600 \\ Jokioinen \\ ${ }^{2)}$ Boreal Kasvinjalostus Oy, Myllytie 10, 31600 Jokioinen \\ 3) All Russia Research Institute of Plant Protection, 189620, Saint-Petersburg, Puskin, sh. Podbelsky, \\ 3, Russia
}

\section{Johdanto}

Ohranverkkolaikku on merkittävin ohran taudinaiheuttaja ja sitä esiintyy kaikilla ohranviljelyalueilla Suomessa. Tauti alentaa sadon määrää pienentämällä jyväkokoa ja heikentää ohran mallastuskelpoisuutta. Taudin oireet näkyvät ohran lehdissä ja lehtitupissa joko kelta-ruskeina verkkomaisina tai laikkumaisina laikkuina. Ohranverkkolaikun aiheuttajasienestä tunnetaan kaksi alamuotoa, jotka aikaansaavat toisistaan poikkeavat oireet isäntäkasvissaan. Ohranverkkolaikun aiheuttaja säilyy kasvukaudesta toiseen saastuneessa kasvijätteessä tai leviää rihmastona siemenen mukana. Tautia voidaan torjua käyttämällä tervettä kylvösiementä tai kasvukauden aikana torjuntaaineruiskutuksia. Myös viljelykierrolla ja viljelemällä taudinkestäviä ohralajikkeita voidaan ehkäistä taudin leviämistä. Ohran esikasviksi parhaiten soveltuvat kaura ja vehnä, jotka vähentävät taudin leviämistä kasvukaudesta toiseen.

Kasvinsuojeluaineiden ja taudinkestävien lajikkeiden käyttöikään vaikuttaa taudinaiheuttajan kyky muuntua torjuntamenetelmiä kestäväksi. Torjuntamenetelmien kestävyys voi syntyä, jos taudinaiheuttajan populaatio altistetaan voimakkaalle valintapaineelle, jolloin populaatiossa menestyvät yksilöt, jotka pystyvät elämään muuttuneissa olosuhteissa (so. torjunta-aineenkestävät tai taudinaiheutuskyvyltään aggressiivisimmat yksilöt). Taudinaiheuttajan muuntumiskykyä ei voida mitata ennalta, koska siihen vaikuttavat $\mathrm{mm}$. taudinaiheuttajan perinnöllinen muuntelevuus, lisääntymistapa ja leviäminen. Monista kasvitaudinaiheuttajista tunnetaan kuitenkin hyvin edellä mainitut ominaisuudet ja niiden muuntumiskykyä voidaan arvioida luotettavasti (McDonald \& Linde 2002). Ohranverkkolaikun perinnöllisen muuntelun määrää on tutkittu jonkin verran, mutta enimmäkseen tutkimus on keskittynyt ohran taudinkestävyyteen ja verkkolaikun taudinaiheutuskykyyn (virulenssi). Tässä tutkimuksessa selvitetään i) ohranverkkolaikun populaatioiden perinnöllisen muuntelun määrää Suomessa ja muualla maailmassa, ii) populaatioiden erilaistumista ja iii) suvullisen ja suvuttoman lisääntymisen tärkeyttä populaatioissa. Tutkimuksesta saatuja tuloksia käytetään arvioitaessa ohranverkkolaikun muuntumiskykyä, kun suunnitellaan ohran kasvinjalostus- tai kasvinsuojeluohjelmaa.

\section{Aineisto ja menetelmät}

Tutkimuksessa käytetään pääasiassa MTT:n kokoelmissa olevia ohranverkkolaikun isolaatteja (yksilöitä), joita on kerätty vuosina 1989 - 1995 MTT:n koeasemilta ympäri Suomea. Varsinaiset populaationäytteet on kerätty vuonna 2001 ja 2002 Jokioisista ja Ylistarosta. Lisäksi kokoelmiin on saatu ulkomaisilta yhteistyökumppaneilta yksittäisiä isolaatteja, jotka ovat eri mantereilta, sekä populaationäytteet vuosilta 2001 ja 2002 Venäjältä.

Isolaattikokoelmat on tuotettu kasvattamalla taudinaiheuttajasieni ulos sairastuneesta ohran lehdestä ja poimimalla kasvustosta steriilisti yksi kuromaitiö edustamaan isolaattia. Isolaattien DNA on eristetty kylmäkuivatusta sienirihmastosta kaupallisella kitillä (Dneasy plant mini kit, QIAGEN). Perinnöllistä muuntelua tutkitaan AFLP-menetelmällä (Vos ym. 1995, Williams ym. 2001), jossa ensin DNA pilkotaan PstI ja MseI -entsyymeillä, jonka jälkeen katkaisukohtiin liitetään T4-ligaasin avulla kappaleet DNA:ta, joita vastaavilla alukkeilla voidaan monistaa kukin DNA-jakso PCR:lla (polymeraasiketjureaktio). PCR toistetaan käyttäen alukkeita, joissa on 1 - 3 valikoivaa emästä. Jaksot erotellaan kapillaarielektroforeesilaitteella, joka pystyy erottelemaan jaksot erittäin tarkasti koon ja elektronisen varauksen perusteella, joka on riippuvainen jakson emäskoostumuksesta. Toisin sanoen perinnöllinen muuntelevuus havaitaan eri pituisina DNA-jaksoina ja joidenkin jaksojen puutteena/olemassaolona. Menetelmä soveltuu erittäin hyvin verkkolaikun aiheuttajan tutkimiseen, koska sienen rihmasto on haploidista (sisältää perimän tiedot yksinkertaisena) ja näin ollen AFLP:n 
avulla voidaan havaita kaikki perimässä olevat erot.

Populaatioiden perinnöllisen muuntelun määrää ja perinnöllistä erilaistumista verrataan tarkoitukseen kehitetyn tietokoneohjelman avulla (Arlequin, Scheiner ym. 1997). Yksittäisiä isolaatteja verrataan tarkastelemalla, montako samaa ja montako erilaista AFLP-merkkiä kahden isolaatin välillä on verrattuna merkkien kokonaismäärään. Populaatioiden erilaistumista mitataan laskemalla havaitun kokonaisvaihtelun osuus populaatioiden yksilöiden välillä ja populaatioiden välillä (Analysis of MOlecular VAriance, Excoffier, Smouse \& Quattro 1992).

Populaatioista määritetään perinnöllisen muuntelun lisäksi sienen kahden alamuodon osuus (verkko- ja laikkutyyppi) tarkoitukseen kehitetyllä spesifisellä PCR:llä (Williams ym. 2001). Taudinaiheuttajan alamuodon määritys on tärkeää kasvinjalostuksen kannalta, koska suurivaikutteiset taudinkestävyysgeenit eri alamuodoille periytyvät erillisinä (Bockelman ym. 1977, Williams ym. 1999, Manninen ym. 2000).

\section{Tulokset}

Tutkimuksen ensimmäisessä osiossa selvitettiin suomalaisten ohranverkkolaikun populaatioiden erilaistumista sekä taudinaiheuttajan alamuotojen esiintymistä populaatioissa. Jokioisista ja Ylistarosta hierarkisesti kerätyt isolaatit analysoitiin kuuden eri alukeparin yhdistelmällä, jolla saatiin 175 AFLPmerkkiä. Isolaatien keskimääräinen AFLP-merkkien samankaltaisuus oli 92,7 \%, vaikka 72 tutkitun isolaatin joukossa ainoastaan kaksi isolaattia olivat täysin samanlaisia ja nämäkin olivat peräisin samalta pellolta Ylistarosta. Keskimääräiset erot isolaatteja pareittain verrattaessa olivat Jokioisissa 15,4 AFLP-merkkiä ja Ylistarossa 11,8, kun kaikkien isolaattien välillä erot olivat 19,6. Suurin osa $(68,5 \%)$ havaitusta perinnöllisestä kokonaisvaihtelusta havaittiin pellon sisällä ja loput peltopopulaatioiden välillä. $\mathrm{F}$-testin mukaan peltopopulaatiot olivat toisistaan poikkeavia $(\mathrm{p}<0,001)$. Kaikki tutkitut isolaatit olivat verkkotyyppiä. Verrattaessa suomalaisia isolaatteja englantilaiseen verkkotyypin isolaattiin ja tsekkiläiseen laikkutyypin isolaattiin, havaittiin, että laikkutyypin isolaatti poikkesi suomalaisista isolaateista keskimäärin 65 merkillä tutkituista 175 merkistä, mikä oli huomattava ero.

Alustavien tulosten mukaan kaikki kolme venäläistä peltopopulaatiota koostuvat myös pelkästään verkkotyypin isolaateista. Kaikki MTT:n kokoelmissa olevat verkko- ja laikkutyypin isolaatit ovat osoittautuneet spesifisellä PCR:lla tutkittaessa oletetuiksi. Toistaiseksi venäläisten verkkolaikkupopulaatioiden perinnöllisen muuntelun määrän vertailu on kesken.

\section{Johtopäätökset}

Suomalaiset ohranverkkolaikun populaatiot ovat erilaistuneita eikä taudinaiheuttajan leviämistä ole tapahtunut ainakaan Jokioisten ja Ylistaron välillä. Aiemmin molemmat verkkolaikun alamuodot olivat yhtä yleisiä Suomessa (Mäkelä 1972), mutta nyt tutkitut populaatiot koostuivat täysin verkkotyypin isolaateista. Syitä verkkotyypin yleistymiseen ei selvitetty tässä tutkimuksessa, mutta ilmeisimmin jokin muutos esim. viljelytekniikassa on voinut suosia verkkotyyppiä. Ilmeisesti laikkutyyppi ei ole kokonaan hävinnyt Suomesta, koska kesällä 2003 löydettiin laikkutyypin isolaatti Jokioisista samalta peltoaukealta, josta populaationäyte oli kerätty vuonna 2001. Toistaiseksi tutkitut kolme venäläistä verkkolaikun populaatiota, jotka ovat peräisin Pietarin alueelta $(2 \mathrm{kpl})$ ja Krasnodarista ovat myös olleet vain verkkotyyppiä, mikä viittaa sen olevan jostain syystä tällä hetkellä vallitseva alamuoto tutkituilla alueilla. Laikkutyyppi esiintyy kuitenkin jopa verkkotyyppiä yleisempänä tietyillä alueilla Sardiniassa, jossa on tutkittu maatiaisohrien verkkolaikkupopulaatioita (Rau ym. 2003). Rau ym. 2003 totesivat myös, että verkko- ja laikkutyyppi eivät lisäänny keskenään luonnossa, mikä sinänsä vähentää taudinaiheuttajan mahdollisuutta muodostaa 'superrotuja', jotka murtaisivat taudinkestävyyden erittäin nopeasti. Oikeanlaisia taudinkestäviä ohralajikkeita voidaan käyttää tehokkaammin, jos tiedetään kumpaa alamuotoa paikkakunnalla esiintyy.

Aiemmin on ajateltu, että verkkolaikku lisääntyisi Suomessa lähinnä suvuttomasti, mutta nyt on havaittu, että molempia pariutumistyyppejä esiintyy yhtäläisesti samalla pellolla. Isolaatit, jotka olivat eri pariutumistyyppiä eivät eronneet toisistaan perimältään merkittävästi, mikä viittaa siihen, että ne eivät ole voineet lisääntyä suvuttomasti erillisinä ryhminä. Suvullisen lisääntymisen todennäköisyys lisää taudinaiheuttajan muuntumiskykyä torjuntamenetelmiä kestäväksi.

Tutkimuksen käynnissä olevissa osioissa on tarkoitus verrata Suomessa havaitun perinnöllisen vaihtelun määrää maailmalta kerätyissä isolaateissa havaittavaan, jotta voidaan arvioida verkkolaikun 
perinnöllistä erilaistumista ja leviämistä maailman laajuisesti. Tietoa voidaan käyttää kasvinjalostuksen ja kasvinsuojelun tukena sekä hyödyntää muiden samankaltaisten kasvitaudin aiheuttajien perustutkimuksessa.

Tässä esitelty tutkimus on väitöskirjatyö, joka on osa MTT:ssa tehtävää pitkäaikaista ohran taudinkestävyyteen keskittyvää tutkimusta. Tutkimusta ovat rahoittaneet Maa -ja Metsätalousministeriö sekä Suomen Kulttuurirahasto.

\section{Kirjallisuus}

Bockelman, H. E., Sharp, E.L. \& Eslick, R.F. 1977. Trisomic analysis of genes for resistance to scald and net blotch in several barley cultivars. Canadian Journal of Botany 55: 2142-2148.

Excoffier, L., Smouse, P.E. \& Quattro, J.M. 1992. Analysis of molecular variance inferred from metric distances among DNA haplotypes: application to human mitochondrial DNA restriction sites. Genetics 131: 479491.

Manninen, O., Kalendar, R., Robinson, J. \& Schulman, A. 2000. Application of BARE-1 retrotransposon markers to the mapping of a major resistance gene for net blotch in barley. Molecular \& General Genetics 264: 325-334.

McDonald, B.A. \& Linde, C. 2002. Pathogen population genetics, evolutionary potential, and durable resistance. Annual Review of Phytopathology 40: 349-379.

Mäkelä, K. 1972. Leaf spot fungi on Barley in Finland. Acta Agralia Fennica 124(3): 22s.

Rau, D., Brown, A.H.D., Brubaker, C.L., Attene, G., Balmas, V., Saba, E. \& Papa, R. 2003. Population genetic structure of Pyrenophora teres Drechs. The causal agent of net blotch in Sardinian landraces of barley (Hordeum vulgare L.). Theoretical and Applied Genetics 106: 947-959.

Scheiner, S., Kueffer, J.-M., Roessli, D. \& Excoffier, L. 1997. Arlequin ver 1.1: A software for population genetic data analysis. Genetics and Biometry Laboratory, University of Geneva, Switzerland.

Vos, P., Hogers, R., Beeker, M., Reijans, M., Van de Lee, T., Hornes, M., Frijters, A., Pot, J., Peleman, J., Kuiper, M. \& Zabeau, M. 1995. AFLP: a new technique for DNA fingerprinting. Nucleid Acids Research 23: 4407-4414.

Williams, K.J., Lichon, A., Gianquitto, P., Kretchemer, J.M., Karakousis, A., Manning, S., Landridge, P. \& Wallwork, H. 1999. Identification and mapping of a gene conferring resistance to the spot form of net blotch (Pyrenophora teres f maculata) in barley. Theoretical and Applied Genetics 99: 323-327.

Williams, K.J., Smyl, C., Lichon, A., Wong, K.Y. \& Wallwork, H. 2001. Development and use of an assay based on the polymerase chain reaction that differentiates the pathogens causing spot form and net form of net blotch of barley. Australasian Plant Pathology 30: 37-40. 